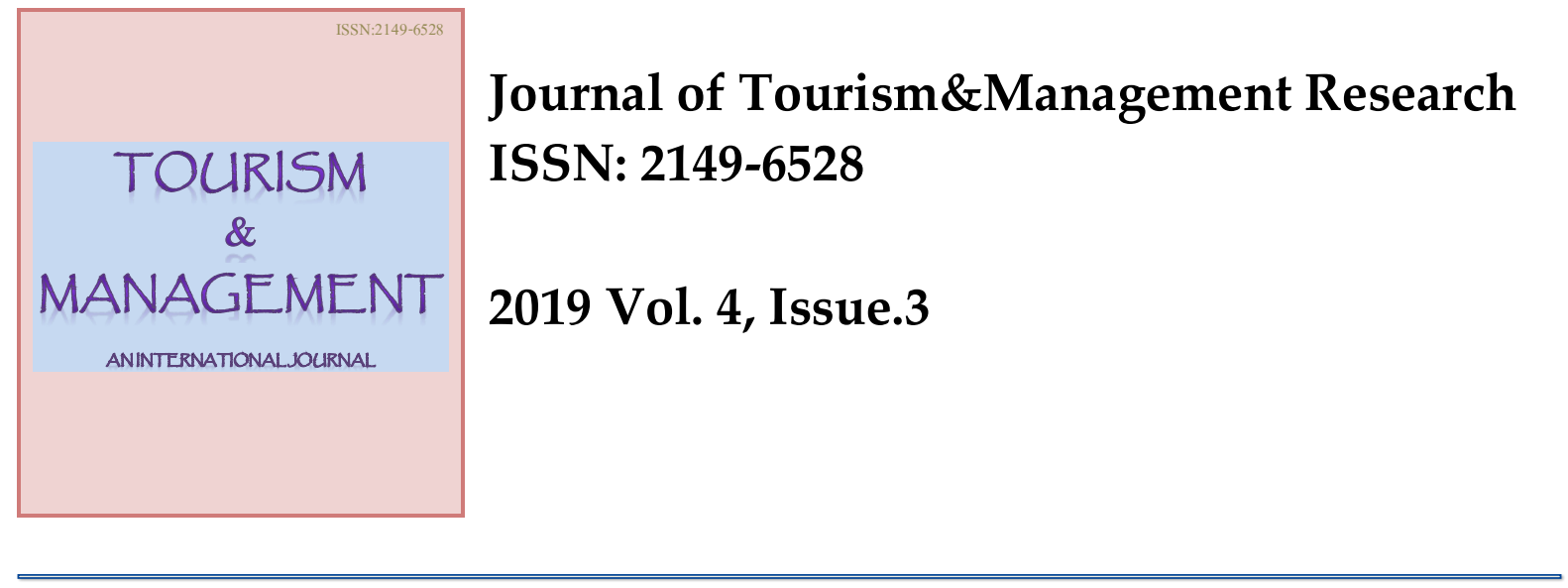

\title{
Determining the Microbiological Quality and Managerial Approaches to Develop Hygienic Process of Meat and Chicken Doners Purchased from Food Enterprises in the Centre of Sinop
}

\begin{abstract}
This research was carried out to determine the microbiological quality of meat and chicken doner samples which were put on sale in 8 enterprises operating in Sinop center, and to determine the methods that can be developed. Due to the high amount of consumption and at the same time it's a touristic food product which called doner improved and selected for the sustainable hygiene and managerial understanding that can be important. The results reveals that the highest number of TAMB (Total Aerobic Mesophilic Bacteria) in meat doner was found to be $3.022 \mathrm{log} \mathrm{cfu} / \mathrm{g}$ in plant $\mathrm{B}$ and the number of yeasts and molds in plant $\mathrm{F}$ was 1.87 $\log \mathrm{cfu} / \mathrm{g}$ and also the number of coliform bacteria was determined in plant B with $1.16 \log$ $\mathrm{cfu} / \mathrm{g}$. The highest total number of TAMB in chicken doner was $2.89 \log \mathrm{cfu} / \mathrm{g}$ in plant $\mathrm{B}$, the number of yeasts and molds was $2.29 \mathrm{log} \mathrm{cfu} / \mathrm{g}$ in plant D and coliform bacteria in $1.07 \mathrm{log}$ $\mathrm{cfu} / \mathrm{g}$ in plant $\mathrm{C}$ was detected. None of the meat/chicken doner samples were found in $\mathrm{S}$. Aureus. As a result, it can be thought that enterprises which sell meat and chicken doner in Sinop province generally do not obey the rules of hygiene and nevertheless, doner kebabs do not have enough amount of bacteria to affect human health, therefore it stays critical to provide related food hygiene trainings for these operators.
\end{abstract}

Keywords: Meat doner, chicken doner, microbiology, administrative measures, sustainable management

JEL Codes: I15, L83, M12

Submitted:25/07/2019; Accepted: 25/10/2019

Aysun Gargaci Kinay, Assistant Professor. (Corresponding Author). Sinop University, School of Tourism and Hotel Management, Department of Gastronomy, Sinop-Turkey. +90 03682715786 Email: aysungargaci34@hotmail.com

Kerem Kaptangil, Assistant Professor. Sinop University, School of Tourism and Hotel Management, Department of Recreation Management, Sinop-Turkey. +90 03682715786 Email:

kerem_kaptangil@hotmail.com 


\section{Introduction}

The main reason of increasing demand for fast-food and doner kebab can be the factors such as rapid urbanization, population growth, shortening the time for eating and the improvements in economic welfare of the society. Besides, there are other factors related to the increase in the consumption of doner kebab like meeting the expectations of consumers in terms of sensory properties, having a high nutritional value and being affordable (Yaman, 1993).

Frequently preferred by the consumers, doners made with chicken or red meat are in a suitable place for bacterial reproduction during the processes of preparation and cooking. Public-health authorities and researchers put forward their worries about the bacteriological conditions of the doners in the places where fast-food meals are sold (Sallam, 2007). The microbiological quality of doner at the time when a consumer buys doner is depend upon the quality of raw ingredients, sufficiency of cooking process, hygiene of the place where doner is made and hygiene of employees. When low-quality meat is used or when the product is not cooked adequately, then the potential problems can arise. Food safety continues to be a public health problem worldwide because food borne illnesses are widespread. Consequently, consumers are increasingly concerned about food safety and quality; and demand more transparency in production and distribution (Aknor et al., 2015).

In addition to the existence of pathogenic microorganisms in food substances, the quantity of these microorganisms can be also a determinant factor in food poisoning. When heattreated products are conserved for a long time in convenient environments (such as room temperature) for microbial growth, owing to the contamination from both viable bacterias and various sources in further processingthat this increase in the number of bacteria in the product results in health problems (Uğur et al., 1993). Ready-to-eat foods with a higher meat content present a very convenient environment to reproduce for microorganisms. Hence, the microorganisms contaminating the product in one of the stages from production to serving can cause food poisoning (Angelidis, 2006).

In the light of the consequences that are presented, This study was conducted to create an applicable model to determine a sustainable management perspective and to identify the microbiological quality of doner at the point where consumers reach doner.

\section{Theoretical Background}

\subsection{Restaurant Sector in Sinop}

There are 66 restaurants in the province of Sinop. These restaurants serve mainly in the local cuisine, while some serve as cafes serving all meals of the day because they are open around the clock. However, in Sinop province, chicken / meat doner is consumed at very high rates as a means of fast consumption. Research which is the subject of chicken/meat döner 10 fast food restaurants services in the province of Sinop where samples were taken from the 8 restaurants examined. The restaurants that were not included in the research started their activities in the timeline after the research phase. The sample represented by the examined restaurants provides the necessary reliability.

\subsection{Doner Preparation Procesess}

Doner is described as a dish of meat obtained respectively by adding leaf tallow as a layer while stringing the meat on the skewer, then shaving and cooking in a vertically positioned stove after the marination of red meat (beef, calf, sheep, meat, goat) and poultry (chicken, turkey) which is in the form of leaf or minced (k1yma) meat, with various additives and condiments for 3-12 hours (Acar, 1996; Küpeli, 1996; Turkish Standards Institute (TSE), 2003). It is informed that doner is produced industrially in various parts of the world and that, today, it is varied as doners made from poultry including chicken and turkey meat in the forms of leaf, leaf-minced and minced meat (Ayaz et al., 1985). 
When doner is adequately cooked at sufficient temperature, because pathogen bacterias in raw ingredients can be destructed, so cooked doner is now regarded as a safe food in microbiological terms (Acar,1996). In addition to this, the heat treatment applied to doner provides only the safety for the surface to a certain depth. In the cases where the slices of doner are cut much more thickly than that of its normal form, and where the cooking time is shortened in the times especially when the demand for doner is high, doner may be served in a condition that the inner parts of it are not cooked adequately (Cebirbay, 2007; Stolle et al., 1993).

When the stages from production to serving are taken into account, because of microbial reproduction inside, doner can threaten the public health if it is not prepared and served under the proper conditions and this is largely caused by the microflora of red meats. Therefore, it is significant to use the meat having lower microflora that is sliced and preserved under the proper condition.

Although the doner should be immediately served hot, there are some cases where it can be kept in sliced form. Nowadays, a certain period of time should pass between the process of preparation of the order received and the delivery of the doner to the consumer by motorcycle couriers. Also, some doner producers tend to sell the doners left from the previous day to the customers in the next day. (Cebirbay 2007; Küpeli \& Kaya, 2004).

\section{Methodology}

In this research, the samples of chicken and doners made from red meat which are sold in enterprises operating in the central district of Sinop were used as material. While 6 of these enterprises sell both chicken doner and doner made from red meat, two of them only sell doner made from red meat. Samples were taken in the sterile packs weighing $100 \mathrm{~g}$, brought to the laboratory under cold condition $\left(+4 \mathrm{C}^{\circ}\right)$ and preserved in the refrigerator until the process of analyzing was done. This research was conducted based on the rules prescribed by BAP (Scientific Research Projects) that the sample materials were collected within three seperate days instead of one single day.

For microbiological analysis, double-sided media, which is a product whose analysis can be performed utilizing medium contact from all surfaces, are used. To identify the total count of mesophilic bacteria, coliform bacteria, yeast, mold, and S. Aureus bacteria, a wipe sample was collected with a ready medium and controlled their reproduction in incubators.

The opinions of the referees of the BAP project were evaluated and in order to reach an objective result, both parts were taken from the sample by direct contact and the samplings were made to obtain the value until $10-5$ by diluting in serial dilutions.

\section{Results}

Microbiological analysis results of 126 cooked samples (72 meat doner and 54 chicken doner) were given as $\log \mathrm{cfu} / \mathrm{g}$ in Table 1 and Table 2. The highest number of TAMB count at meat doner was found in plant B with 3,022 log cfu / g, yeast and mold count in plant F with 1,87 $\log \mathrm{cfu} / \mathrm{g}$, the number of coliform bacteria was detected in plant B with 1,16 log cfu / g. S. Aureus was not found in any of the samples.

Table 1: Number of Microorganisms in Meat Doner.

\begin{tabular}{lllll}
\hline Plants & TAMB & Yeast and Mold & S. Aureus & Coliform \\
\hline A & $2,977 \pm 0,12$ & $0,929 \pm 0,60$ & $0,000 \pm 0$ & $0,500 \pm 0,11$
\end{tabular}




\begin{tabular}{lcccc}
\hline B & $3,022 \pm 0,13$ & $1,430 \pm 0,58$ & $0,000 \pm 0$ & $1,161 \pm 0,19$ \\
\hline C & $1,060 \pm 1,12$ & $0,588 \pm 0,11$ & $0,000 \pm 0$ & $0,772 \pm 0,8$ \\
\hline D & $2,199 \pm 0,28$ & $1,278 \pm 0,19$ & $0,000 \pm 0$ & $0,801 \pm 0,07$ \\
\hline E & $0,389 \pm 0,54$ & $0,000 \pm 0$ & $0,000 \pm 0$ & $0,000 \pm 0$ \\
\hline F & $3,019 \pm 0,41$ & $1,878 \pm 0,72$ & $0,000 \pm 0$ & $1,370 \pm 0,09$ \\
\hline G & $2,637 \pm 0,22$ & $1,239 \pm 0,31$ & $0,000 \pm 0$ & $0,000 \pm 0$ \\
\hline H & $0,929 \pm 0,71$ & $0,000 \pm 0$ & $0,000 \pm 0$ & $0,000 \pm 0$
\end{tabular}

The highest number of TAMB count was found in chicken doner was found in plant B with $2.89 \log \mathrm{cfu} / \mathrm{g}$, yeast and mold count was found in plant D with $2.29 \mathrm{log} \mathrm{cfu} / \mathrm{g}$ and coliform bacteria in plant $\mathrm{C}$ with $1.07 \mathrm{log} \mathrm{cfu} / \mathrm{g}$. S. Aureus was not found in any of the samples.

Table 2: Number of Microorganisms in Chicken Doner.

\begin{tabular}{lcccc}
\hline Plants & TAMB & Yeast and Mold & S. Aureus & Coliform \\
\hline A & $2,011 \pm 0,22$ & $1,806 \pm 0,47$ & $0,000 \pm 0$ & $0,389 \pm 0,31$ \\
\hline B & $2,898 \pm 0,30$ & $1,782 \pm 0,35$ & $0,000 \pm 0$ & $0,812 \pm 0,43$ \\
\hline C & $1,908 \pm 0,26$ & $1,651 \pm 0,26$ & $0,000 \pm 0$ & $1,079 \pm 0,38$ \\
\hline D & $1,827 \pm 0,50$ & $2,292 \pm 0,54$ & $0,000 \pm 0$ & $0,739 \pm 0,03$ \\
\hline E & $1,239 \pm 0,31$ & $0,500 \pm 0,09$ & $0,000 \pm 0$ & $0,000 \pm 0$ \\
\hline H & $3,142 \pm 0,71$ & $1,509 \pm 0,48$ & $0,000 \pm 0$ & $0,389 \pm 0,20$ \\
\hline
\end{tabular}

\section{Conclusion, Implications and Limitations}

The count of TMAB is regarded as a significant criterion to determine the microbiological quality of cooked meat products like doner. (Stolle et al., 1993) The limit value is estimated for such products as < $5 \log \mathrm{kob} / \mathrm{g}$. (Aran, 1988; Stolle et al., 1993).

In our research, TMAB count of doner made from meat was assessed on a scale ranging between $0,389 \log \mathrm{cfu} / \mathrm{g}$ and 3,022 log cfu/g. TMAB count of cooked doner was calculated between 1,23 log cfu/g and 3,14 log cfu/g. In the measurement conducted by dilution, these values are estimated between 10-1 and 10-3 cfu/g. In an empirical research carried out by Bostan (2011) to put forward the microbiological quality of cooked doners, he assessed the TMAB count of doner made from red meat mostly at the level of 103 and $104 \mathrm{kob} / \mathrm{g}$ and in some samples, this count was reported as high as $106 \mathrm{cfu} / \mathrm{g}$. In the research conductedon doner made from red meat in Kars province by Elmalı et al. (2005) reported the count of TAMB as lower than 102 and $106 \mathrm{cfu} / \mathrm{g}$. Öksüztepe (2014), in his study on chicken and doner made from meat in Elazı̆ province, assessed total mesophilic aerobic bacteria count 
respectively as 4.98 and $5.11 \mathrm{log} \mathrm{kob} / \mathrm{g}$. When the current research findings and previous studies findings are compared, it seems that there is a similarity among the value in terms of the high level of count of TMAB, but it may be thought that the differences among these values are depend upon the quality of the meat used in analyses, bacterial load that can be transmitted during preparation and the number of the bacteria that can be contaminated during serving.

In the current study Yeast and mold count is estimated between 0 and 1,87 log cfu/g in the samples of doner made from red meat and estimated between $0,5 \mathrm{log} \mathrm{cfu} / \mathrm{g}$ ile 2,29 in the samples of chicken doner. Compared with previous studies on doner, yeast and mold count is lower in the samples taken from Sinop province. It is thought that this is because the doner enterprises in Sinop province comply with some hygiene measures.

It is reported that the presence of bacterias from the coliform group in the heat-treated or cooked products can be caused by inadequate processing conditions or from the contamination after processing (Göktan, 1990). In our research, the count of coliform group bacteria is assessed between 0 and 1,43 log cfu/g in the samples of doner made from meat and is assessed between 0 and 2,07 log cfu/g in the samples of chicken doner. The results of the analysis are similar to the results yielded by Öksüztepe (2014) but these results are lower than the results obtained by Elmalı (2005) and Hampikyan (2008). The presence of coliform group bacteria in the cooked doner samples is thought to be caused by staff and equipment in the production stages.

It is reported that doner is significant in terms of Staphylococcus aureus and that Staphylococcus aureus can not be destructed if doner is not adequately cooked (Küpeli, 1996). In most of the microbiological researches on doner made from red meat and chicken doner, Staphylococcus aureus was encountered, but in this research, we carried out in Sinop, Staphylococcus aureus was not found in any of the samples analyzed. The main reasons behind the differences and similarities between chicken doner and doner made from red meat which is microbiologically examined may be depending on the factors such as the spices used for marination, the bacterias existing naturally in chicken doner and doner made from red meat, the hygiene of the places of production and personal hygiene of employees.

In the process of providing the samples, personal hygiene of employees, hygiene of the enterprises, the equipment used in serving were monitored. After monitoring, it was realized that the many behaviors should be changed such as not using gloves of staff while slicing doner, putting doner in plates without gloves, using the same knife for chicken doner and doner made from red meat, using the same towel for cleaning their hands and tables.

In general terms, the most important conditions for producing a product which has high microbiological quality and harmless to human health include quality raw ingredients, personal hygiene of employees and hygiene of equipment and the adequate temperature for cooking.

The enterprises $\mathrm{B}, \mathrm{F}$, and $\mathrm{C}$ are thought to be hygienically inconvenient especially in terms of a load of coliform group bacteria and TAMB. Coliform group bacteria usually become inactive due to the effect of temperature. Hence, it is crucial that doner that is prepared to serve must be cooked adequately.

As a result, it is concluded that the enterprises in Sinop do not comply with the hygiene measures but the presence of bacteria in doner is not at the level threatening to human health, and necessary measures must be taken to produce and consume doner safely, and the enterprises must train their employees regardingpersonal hygiene and also the system concerning food safety management system must be practiced.

When it is evaluated in managerial terms, taking advantage of the perception of hygiene as an element for providing a competitive advantage, in the current conditions of competition, is a factor that many enterprises can adopt. 
Specifically, the hygiene factors are so important for the basic value and skills presented by enterprises served in the food manufacturing sector in their current field of activity. In addition to the efforts to determine consumer behaviors and preferences, forming consumer attitudes and behaviors in today's conditions of competition are now considered as an important competitive element of enterprises. To achieve this, food enterprises must carry out various researches to determine the factors that can remain at the forefront of customer preferences to reveal the factors that can be the reason of choice in the undifferentiated target market. It is thought that the hygiene factor, which will be at the top of the ranking related to the customers' preference, will sometimes gain such a high level of importance that they can form the missions of the enterprises accordingly. At the same time, it is considered that the brand positioning in this direction provides significant advantages in terms of making a difference in today's conditions of competition. The reshaping of conditions of competition, product quality and understanding of quality which is the degree of meeting the needs by bringing hygiene to the forefront among the product components may lead to the reemergence of the hygiene factor which is sometimes overlooked in the customer preferences and to make it new field of competition with the new approaches. The efforts exerted by other enterprises that are willing to respond to the requirements of this new field of competition that can be formed in this way to include the elements of hygiene in their brand values will increase the importance of the hygiene factor in the quality component in the market. This situation will help to establish a ready-meal market where quality will increasingly become a standard among the enterprises in the market as sustainable hygiene rules. This will help to establish a ready-made food market where quality will increase by identifying sustainable hygiene rules that become a standard among the enterprises in the market.

The current study has limitations as well, such as the fact that the samples taken in the research can give different results on different days. In addition, the enterprises that started to work in the research process due to process constraints were not included in the research. The repeating the research within a larger sample at different times in accordance with the scientific principle may yield different results.

\section{Acknowledgements}

This work was supported by the Scientific Research Projects Unit of Sinop University, Project No. TİYO-1901-18-51. The authors would like to thank Sinop University.

\section{References}

Acar M.S. (1996), Kasaplık Hayvan Etleri ve Tavuk Etinden Yapılan Döner Kebapların Mikrobiyolojik Kalitesinin Karşılaştırmalı Araştırması. (Doktora Tezi). İstanbul Üniversitesi, Sağllk Bilimleri Enstitüsü, İstanbul.

Akonor, P. T., \& Akonor, M. A. (2013). Food Safety Knowledge: The case of domestic food handlers in Accra. European Journal of Nutrition \& Food Safety, 99-111.

Al-Shadefat, B. (2011). Tüketim sürecinde döner kebaplarda Salmonella spp. Varlığının araştırılması (Doktora Tezi). Selçuk Üniversitesi Sağlık Bilimleri Enstitüsü.

Angelidis, A.S., Chronis, E.N., Papageorgiou, D.K., Kazakis I.I., Arsenoglou, K.C. \& Stathopoulos, G.A. (2006). Non- lactic acid, contaminating microbial flora in readyto-eat foods: a potential food- quality index. Food Microbiol, 23, pp.95-100.

Aran N. (1988). İstanbul piyasasında tüketime sunulan bazı hazır gıdaların tüketici sağlığ yönünden değerlendirilmesi. Gıda Sanayii, 2, pp.36-42. 
Ayaz, M., Othman, F.A., Bahareth, T.O., Al-Sogair, M.A. \& Sawaya, W.N. (1985). DATE Microbial quality of shawarma in Saudi Arabia. Journal of Food Protection, 48(9), 811-814.

Bostan, K., Yılmaz, F., Muratoğlu, K. \& Aydın, A.(2011). Pişmiş döner kebaplarda mikrobiyolojik kalite ve mikrobiyel gelişim üzerine bir araştırma. Kafkas Universitesi Veterinerlik Fakulte Dergisi, 17(5), 781-6.

Cebirbay, M.A. (2007). Dönerlerde Satış Süresi Boyunca Mikrobiyolojik Kalitede Meydana Gelen Değişmelerin Araştırılması. Yüksek Lisans Tezi Selçuk Üniversitesi, Sağlık Bilimleri Enstitüsü, Konya.

Göktan D. (2010). Gidaların Mikrobiyal Ekolojisi, Et Mikrobiyolojisi. Ege Ünivesrsitesi Mühendislik Fakulte Yayin No: 21. Bornova/İzmir.

Elmalı, M., Ulukanlı, Z., Tuzcu, M., Yaman, H. and Çavl1, P. (2005). Microbiological Quality of Beef Doner Kebabs in Turkey. Arch Lebensmittelhyg, 56, 25-48.

Hampikyan, H., Ulusoy, B., Bingöl, E.B., Çolak, H. and Akhan, M. (2008). İstanbul'da tüketime sunulan bazı 1zgara tipi gidalar ile salata ve mezelerin mikrobiyolojik kalitelerinin belirlenmesi. Türk Mikrobiyol Cemiyet Dergisi, 38(2), 87-94.

Jöckel, J. \& Stengel, G. (1984). Döner kebab-Unterschung und beurteilung einer türkischen spezialitat (Döner kebap manufacturing and assessment of Turkish specialities). Fleischwirtschaft, 64(5), 527-540.

Küpeli, V. (1996). Yaprak Dönerlerin Kimyasal Bileşimi ve Mikrobiyolojik Kalitesi”, Atatürk Üniversitesi, Fen Bilimleri Enstitüsü, Gıda Mühendisliği Anabilim Dalı, (Yüksek Lisans Tezi) Erzurum.

Küpeli, G.V, and Kaya, M. (2004). Yaprak Dönerlerin Mikrobiyolojik Kalitesi ve Kimyasal Bileşimi, Turkish Journal of Veterinary and Animal Science, 28, 1097-1103.

Mattsson, J. and Helmersson, H. (2007). Eating Fast Food: Attitudes of High-School Students, International Journal of Consumer Studies, 31, 117-121.

Sallam, K.I. (2007). Prevalence of Campylobacter in chicken and chicken by-products retailed in Sapporo area, Hokkaido, Japan. Food Control, 18, 1113-1120.

Stolle, A., Eisgruber, H., Kerschhofer, D. and Krauße, G. (1993). Untersuchungen zur Verkehrsauffassung und Mikrobiologisch-Hygienishen Beschaffenheit im raum München. Fleischwirtschaft, 73 (9), 938-943.

TSE. (2003). TS 11859, "Döner Eti-Pişmemiş", Türk Standartları Enstitüsü, 1-7. Küpeli, V., "Yaprak Dönerlerin Kimyasal Bileşimi ve Mikrobiyolojik Kalitesi", Atatürk Üniversitesi, Fen Bilimleri Enstitüsü, Glda Mühendisliği Anabilim Dall, (Yüksek Lisans Tezi) Erzurum.

Uğur, M., Nazlı, B. and Bostan, K. (2001). Gıda Hijyeni. s. 57-58, Teknik Yayınevi, İstanbul. Yaman, R.(1993). "Döner Kebabın Hikayesi”. Türk Mutfak Kültürü Üzerine Araştırmalar, Türk Halk Kültürünü Araştırma ve Tanıtma Vakfi Yayınlarl, No: 3, 92-101.

\section{Author Biography}

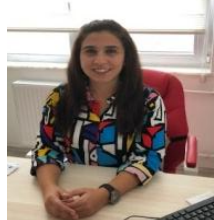

Aysun GARGACI KINAY is Assistant Professor Sinop University, School of Tourism and Hotel Management, Department of Gastronomy, Sinop-Turkey. She has research publications in the field. 


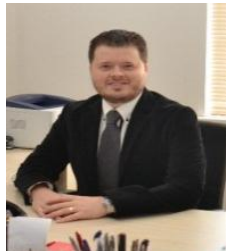

Kerem KAPTANGiL is Assistant Professor, Sinop University, School of Tourism and Hotel Management, Department of Recreation Management, Sinop-Turkey.He has publications in hospitality management and management journals. He authored two books related to human resource management and economy. 